Supporting Information

\title{
Tuning Energy Levels and Film Morphology in Benzodithiophene- Thienopyrrolodione Copolymers Via Nitrogen Substitutions
}

Teck Lip Dexter Tam*, Ting Ting Lin

Agency of Science, Technology and Research (A*STAR), Institute of Materials Research and Engineering (IMRE), 2 Fusionopolis Way, Innovis, Singapore 138634, Singapore

\section{Experimental Methods \& Details}

All reagents were purchased from Sigma Aldrich unless otherwise stated. Bromanilic acid was purchased from TCI America. Column chromatography was carried out with Merck silica-gel (230 - 400 mesh). ${ }^{1} \mathrm{H}$ and ${ }^{13} \mathrm{C}$ data were performed on Bruker Avance III $500 \mathrm{MHz}$ system with chemical shifts referenced to $\mathrm{CDCl}_{3}$ or DMSO-d respectively. Matrix assisted laser desorption/ionization time-of-flight (MALDI-TOF) mass spectra were obtained on a Bruker Autoflex III Mass Spectrometer. Elemental analysis was carried out by Midwest Microlab, LLC. UV-Vis absorption spectra were recorded on a Lambda 900 Spectrometer from Perkin Elmer. Cyclic voltammetry (CV) experiments were performed using BASi C-3 Cell Stand. Thin film CV measurements of the synthesized polymers on platinum were recorded in dry acetonitrile with $0.1 \mathrm{M}$ tetrabutylammonium hexafluorophosphate as supporting electrolyte (scan rate of 100 $\mathrm{mV} \cdot \mathrm{s}^{-1}$ ). The experiments were performed at room temperature with a conventional three electrodes configuration consisting of a platinum working electrode, a platinum wire counter electrode, and an $\mathrm{Ag} / \mathrm{AgCl}$ in $3 \mathrm{M} \mathrm{NaCl}$ reference electrode. Polymer thin film XRD samples were prepared by spincoating polymers dissolved in 1,2-dichlorobenzene onto silicon substrates (annealing at $150{ }^{\circ} \mathrm{C}$ for 30 mins) and were recorded by using SmartLab (Rigaku) equipped with a rotating anode $\mathrm{Cu} \quad \mathrm{Ka}$ X-ray generator. Thermogravimetry analysis (TGA) was measured using TG50 (Mettler Toledo) instrument. The temperature range from 25 to $800{ }^{\circ} \mathrm{C}$ was scanned at a heating rate of 10 ${ }^{\circ} \mathrm{C} / \mathrm{min}$ under nitrogen atmosphere. Differential scanning calorimetry (DSC) were 
measured using DSC822e (Mettler Toledo) instrument with temperature range of 25 to $300{ }^{\circ} \mathrm{C}$ and a heating rate of $10{ }^{\circ} \mathrm{C} / \mathrm{min}$ under nitrogen atmosphere. Molecular structures of the oligomers of both PBDTTPD and pBBTzTPD from $n=1$ to 8 were geometry optimized using DFT B3LYP 6-31G $(\mathrm{d}, \mathrm{p})$ level of theory in the gas phase. TD-DFT calculations of the first twelve excited states were performed on the optimized structures of PBDTTPD and PBBTzTPD for $n=3$ using the same level of theory in the gas phase.

$\left(\mathbf{H}_{2} \mathbf{N}\right)_{2}$-BBTz-dione. Bromanilic acid $(4.244 \mathrm{~g}, 14.25 \mathrm{mmol})$ was dissolved in $280 \mathrm{~mL}$ of DMF in a round bottom flask under $\mathrm{N}_{2}$ atmosphere. Thiourea $(2.223 \mathrm{~g}, 29.20 \mathrm{mmol}$ ) was added and the reaction was allowed to stir at room temperature for 2 hours. Triethylamine (4.17 mL, $29.92 \mathrm{mmol}$ ) was added dropwisely and the reaction was heated up to $80{ }^{\circ} \mathrm{C}$ for 1 day. The reaction was allowed to cool to room temperature and poured into $400 \mathrm{~mL}$ of methanol. The precipitate was filtered and washed with plenty of methanol to yield the crude product (3.064 g, $85 \%$ ) without further purification. ${ }^{1} \mathrm{H}$ NMR (500 MHz, DMSO) $\delta 8.39$ (s, 4H). ${ }^{13} \mathrm{C}$ NMR (126 MHz, DMSO) $\delta 173.04,172.57,153.84,125.51$. MALDITOF-MS m/z: $253.38\left(\mathrm{M}+\mathrm{H}^{+}\right)$; calcd. for $\mathrm{C}_{8} \mathrm{H}_{4} \mathrm{~N}_{4} \mathrm{O}_{2} \mathrm{~S}_{2}=252.27$.

BBTz-dione. $\left(\mathbf{H}_{\mathbf{2}} \mathbf{N}\right)_{2}$-BBTz-dione $(3.0 \mathrm{~g}, 11.89 \mathrm{mmol})$ was suspended in $200 \mathrm{~mL}$ of dry DMF at $70{ }^{\circ} \mathrm{C}$ in a round bottom flask under $\mathrm{N}_{2}$ atmosphere. tert-butyl nitrite $(8.49 \mathrm{~mL}$, $71.38 \mathrm{mmol}$ ) was added dropwisely and the reaction was allowed to stir overnight. The reaction was cooled to room temperature and volatiles were removed. Methanol was added to the residue and the solids were filtered. The residue was wash extensively with methanol to yield the crude product $(1.364 \mathrm{~g}, 52 \%)$ without further purification. ${ }^{1} \mathrm{H}$ NMR (500 MHz, DMSO) $\delta 9.55$ (s, 2H). ${ }^{13} \mathrm{C}$ NMR (126 MHz, DMSO) $\delta 172.70,161.47$, 153.90, 141.70. MALDI-TOF-MS m/z: 221.98 (M'); calcd. for $\mathrm{C}_{8} \mathrm{H}_{2} \mathrm{~N}_{2} \mathrm{O}_{2} \mathrm{~S}_{2}=221.96$.

BBTz(OEH) 2. BBTz-dione (1.0 g, $4.50 \mathrm{mmol})$, sodium dithionite $(1.88 \mathrm{~g}, 10.80 \mathrm{mmol})$ and potassium carbonate $(6.21 \mathrm{~g}, 44.93 \mathrm{mmol})$ were suspended in $25 \mathrm{~mL}$ of DI water in a round bottom flask under $\mathrm{N}_{2}$ atmosphere. The reaction was stirred at room temperature for 2 hours. 2-ethylhexylbromide $(2.4 \mathrm{~mL}, 13.50 \mathrm{mmol})$ was added and the reaction was stirred at $60{ }^{\circ} \mathrm{C}$ for 2 days. The reaction was cooled to room temperature, poured into 100 
$\mathrm{mL}$ of DI water and extracted using diethyl ether $(3 \times 100 \mathrm{~mL})$. The organics were dried over anhydrous magnesium sulphate, filtered and concentrate. The product was purified via silica column chromatography (100\% hexane to $30 \%$ hexane $70 \%$ dichloromethane) to yield a light yellow liquid (1.318 g, $65 \%) .{ }^{1} \mathrm{H} \mathrm{NMR}\left(500 \mathrm{MHz}, \mathrm{CDCl}_{3}\right) \delta 8.94(\mathrm{~s}, 2 \mathrm{H})$, $4.63(\mathrm{~m}, 4 \mathrm{H}), 1.79(\mathrm{~m}, 2 \mathrm{H}), 1.67-1.29(\mathrm{~m}, 16 \mathrm{H}), 0.97$ (t, $J=7.5 \mathrm{~Hz}, 6 \mathrm{H}), 0.91$ (t, $J=7.0$ $\mathrm{Hz}, 6 \mathrm{H}) .{ }^{13} \mathrm{C} \mathrm{NMR}\left(126 \mathrm{MHz}, \mathrm{CDCl}_{3}\right) \delta 153.63,153.61,142.48,126.19,40.44,30.52$, 29.24, 23.90, 23.25, 14.27, 11.35. Anal. Calcd for $\mathrm{C}_{24} \mathrm{H}_{36} \mathrm{~N}_{2} \mathrm{O}_{2} \mathrm{~S}_{2}: \mathrm{C}, 64.24 ; \mathrm{H}, 8.09 ; \mathrm{N}$, 6.24; O, 7.13; S, 14.29. Found: C, 64.50; H, 8.34; N, 6.47. MALDI-TOF-MS m/z: 449.44 $\left(\mathrm{M}+\mathrm{H}^{+}\right)$; calcd. for $\mathrm{C}_{24} \mathrm{H}_{36} \mathrm{~N}_{2} \mathrm{O}_{2} \mathrm{~S}_{2}=448.22$.

BBTz(ThEH)2. 2-(2-ethylhexyl)thiophene (0.583 g, $2.97 \mathrm{mmol})$ was dissolved in $3 \mathrm{~mL}$ of dry THF at $-78{ }^{\circ} \mathrm{C}$ in a round bottom flask under $\mathrm{N}_{2}$ atmosphere. $n$-BuLi (2.61 M, 1.14 $\mathrm{mL}, 2.98 \mathrm{mmol}$ ) was added dropwisely and the reaction was allowed to warm up to room temperature and stirred for 30 mins before cooling back down to $-78{ }^{\circ} \mathrm{C}$. In a separate round flask, BBTz-dione $(0.220 \mathrm{~g}, 0.99 \mathrm{mmol})$ was suspended in $10 \mathrm{~mL}$ of dry THF at $78{ }^{\circ} \mathrm{C}$ under $\mathrm{N}_{2}$ atmosphere. The lithiated 2-(2-ethylhexyl)thiophene solution was transferred and added dropwisely to the suspended BBTz-dione. The reaction was allowed to warm up to room temperature. $\mathrm{SnCl}_{2}(1.426 \mathrm{~g}, 7.52 \mathrm{mmol})$ dissolved in $2 \mathrm{~mL}$ $10 \% \mathrm{HCl}$, was added dropwisely to the reaction and heated at $60{ }^{\circ} \mathrm{C}$ overnight. The reaction was allowed to cool to room temperature, poured into $100 \mathrm{~mL}$ of DI water and extracted using diethyl ether $(3 \times 50 \mathrm{~mL})$. The organics were dried over anhydrous magnesium sulphate, filtered and concentrate. The product was purified via silica column chromatography (100\% hexane to $97 \%$ hexane $3 \%$ ethyl acetate) to yield a yellow solid (231 mg, 40 \%). ${ }^{1} \mathrm{H}$ NMR (500 MHz, $\left.\mathrm{CDCl}_{3}\right) \delta 9.15(\mathrm{~s}, 2 \mathrm{H}), 7.74(\mathrm{~d}, J=3.6 \mathrm{~Hz}$, 2H), 6.92 (d, $J=3.7 \mathrm{~Hz}, 2 \mathrm{H}), 2.87$ (d, $J=6.8 \mathrm{~Hz}, 4 \mathrm{H}), 1.71$ (m, 2H), $1.47-1.29$ (m, 16H), $0.95-0.89(\mathrm{~m}, 12 \mathrm{H}) .{ }^{13} \mathrm{C}$ NMR $\left(126 \mathrm{MHz}, \mathrm{CDCl}_{3}\right) \delta$ 155.11, 148.48, 147.59, $136.22,133.16,128.85,125.48,123.07,41.55,34.40,32.63,29.06,25.77,23.19,14.32$, 11.00. Anal. Calcd for $\mathrm{C}_{32} \mathrm{H}_{40} \mathrm{~N}_{2} \mathrm{~S}_{4}: \mathrm{C}, 66.16 ; \mathrm{H}, 6.94 ; \mathrm{N}, 4.82 ; \mathrm{S}, 22.08$. Found: $\mathrm{C}, 66.05$; $\mathrm{H}, 7.19 ; \mathrm{N}, 4.63$. MALDI-TOF-MS m/z: $579.61\left(\mathrm{M}^{+}\right)$; calcd. for $\mathrm{C}_{32} \mathrm{H}_{40} \mathrm{~N}_{2} \mathrm{~S}_{4}=580.21$. 
$\left(\mathbf{H}_{2} \mathbf{N}\right)_{2}-\mathbf{B B T z}(\mathbf{O E H})_{2} \cdot\left(\mathbf{H}_{2} \mathbf{N}\right)_{2}$-BBTz-dione (1.0 g, $\left.3.96 \mathrm{mmol}\right)$, sodium dithionite (1.66 $\mathrm{g}, 9.53 \mathrm{mmol})$ and potassium carbonate $(5.48 \mathrm{~g}, 39.65 \mathrm{mmol})$ were suspended in $10 \mathrm{~mL}$ of DI water and $25 \mathrm{~mL}$ of DMF in a round bottom flask under $\mathrm{N}_{2}$ atmosphere. The reaction was heated to $100{ }^{\circ} \mathrm{C}$ for 2 hours. 2-ethylhexylbromide $(2.11 \mathrm{~mL}, 11.87 \mathrm{mmol})$ was added and the reaction was stirred at $100{ }^{\circ} \mathrm{C}$ for 1 day. The reaction was cooled to room temperature, poured into $200 \mathrm{~mL}$ of DI water and extracted using diethyl ether (3 x $100 \mathrm{~mL}$ ). The organics were dried over anhydrous magnesium sulphate, filtered and concentrate. The product was purified via silica column chromatography (100\% hexane to $75 \%$ hexane $25 \%$ ethyl acetate) to yield a white solid ( $0.782 \mathrm{~g}, 41 \%$ ). ${ }^{1} \mathrm{H}$ NMR (500 $\left.\mathrm{MHz}, \mathrm{CDCl}_{3}\right) \delta 5.65(\mathrm{~s}, 4 \mathrm{H}), 4.24(\mathrm{~m}, 4 \mathrm{H}), 1.72(\mathrm{~m}, 2 \mathrm{H}), 1.61-1.31(\mathrm{~m}, 16 \mathrm{H}), 0.93(\mathrm{t}, J$ $=7.5 \mathrm{~Hz}, 6 \mathrm{H}), 0.89(\mathrm{t}, J=7.0 \mathrm{~Hz}, 6 \mathrm{H}) .{ }^{13} \mathrm{C} \mathrm{NMR}\left(126 \mathrm{MHz}, \mathrm{CDCl}_{3}\right) \delta 164.14,139.19$, $139.09,123.47,76.32,40.25,30.39,29.18,23.76,23.25,14.28,11.24$. A satisfactory elemental analysis could not be obtained due to the instability of the compound. MALDITOF-MS m/z: $479.43\left(\mathrm{M}+\mathrm{H}^{+}\right)$; calcd. for $\mathrm{C}_{24} \mathrm{H}_{38} \mathrm{~N}_{4} \mathrm{O}_{2} \mathrm{~S}_{2}=478.24$.

$\mathbf{B r}_{2}-\mathbf{B B T z}(\mathbf{O E H})_{2} \cdot\left(\mathbf{H}_{2} \mathbf{N}\right)_{2}-\mathbf{B B T z}(\mathbf{O E H})_{2}(0.241 \mathrm{~g}, 0.50 \mathrm{mmol})$ and $\mathrm{CuBr}_{2}(0.270 \mathrm{~g}, 1.21$ mmol) was suspended in $20 \mathrm{~mL}$ of dry acetonitrile at $0{ }^{\circ} \mathrm{C}$ in a round bottom flask under $\mathrm{N}_{2}$ atmosphere. tert-butyl nitrite $(0.13 \mathrm{~mL}, 1.09 \mathrm{mmol})$ was added dropwisely and the reaction was allowed to stir at $0{ }^{\circ} \mathrm{C}$ for 30 mins. The reaction was allowed to warm up to room temperature and stirred for 1 hour before heating up to $65{ }^{\circ} \mathrm{C}$ overnight. The reaction was cooled to room temperature, poured into $100 \mathrm{~mL}$ of DI water and extracted using dichloromethane $(3 \times 50 \mathrm{~mL})$. The organics were dried over anhydrous magnesium sulphate, filtered and concentrate. The product was purified via silica column chromatography (100\% hexane to $80 \%$ hexane $20 \%$ dichloromethane) to yield an offwhite solid (0.127 g, $42 \%) .{ }^{1} \mathrm{H}$ NMR (500 MHz, $\left.\mathrm{CDCl}_{3}\right) \delta 4.55(\mathrm{~m}, 4 \mathrm{H}), 1.72(\mathrm{~m}, 2 \mathrm{H})$, $1.62-1.34(\mathrm{~m}, 16 \mathrm{H}), 0.97(\mathrm{t}, J=7.5 \mathrm{~Hz}, 6 \mathrm{H}), 0.92(\mathrm{t}, J=7.0 \mathrm{~Hz}, 6 \mathrm{H}) .{ }^{13} \mathrm{C}$ NMR $(126$ $\left.\mathrm{MHz}, \mathrm{CDCl}_{3}\right) \delta 140.58,140.36,137.56,129.09,76.76,40.29,30.49,29.24,23.90,23.22$, 14.28, 11.35. Anal. Calcd for $\mathrm{C}_{24} \mathrm{H}_{34} \mathrm{Br}_{2} \mathrm{~N}_{2} \mathrm{O}_{2} \mathrm{~S}_{2}$ : C, 47.53; H, 5.65; Br, 26.35; N, 4.62; O, 5.28; S, 10.57. Found: C, 47.68; H, 5.78; N, 4.47. MALDI-TOF-MS m/z: 605.51 $\left(\mathrm{M}+\mathrm{H}^{+}\right)$; calcd. for $\mathrm{C}_{24} \mathrm{H}_{34} \mathrm{Br}_{2} \mathrm{~N}_{2} \mathrm{O}_{2} \mathrm{~S}_{2}=604.04$. 
General procedures for direct arylation polymerizartion of both PBDTTPD and pBBTzTPD. The dibromo compound $(0.20 \mathrm{mmol})$, TPD $(52.7 \mathrm{mg}, 0.20 \mathrm{mmol})$, Herrmann's catalyst (7.5 mg, $4 \mathrm{~mol} \%)$, tris (o-methoxyphenyl)phosphine $(5.6 \mathrm{mg}, 8 \mathrm{~mol}$ $\%$ ), anhydrous cesium carbonate $(130.3 \mathrm{mg}, 0.4 \mathrm{mmol})$ and pivalic acid $(6.1 \mathrm{mg}, 30 \mathrm{~mol}$ $\%$ ) were added into a round bottom flask, carefully sealed and put under vacuum for 1 hour. The round bottom flask was refilled with nitrogen and $1 \mathrm{~mL}$ of toluene was added. The reaction was heated at $120{ }^{\circ} \mathrm{C}$ for 2 days. The reaction was cooled to room temperature and precipitated in methanol. The solids were filtered, washed with methanol and dried. Soxhlet extraction was carried out using acetone (1 hour), hexane (1 hour) and 1,2-dichlorobenzene. The 1,2-dichlorobenzene fraction was concentrated and reprecipitated in methanol to yield the polymer. pBDTTPD, dark blue solids, $92 \%$ yield. pBBTzTPD, black solids, $96 \%$ yield. 


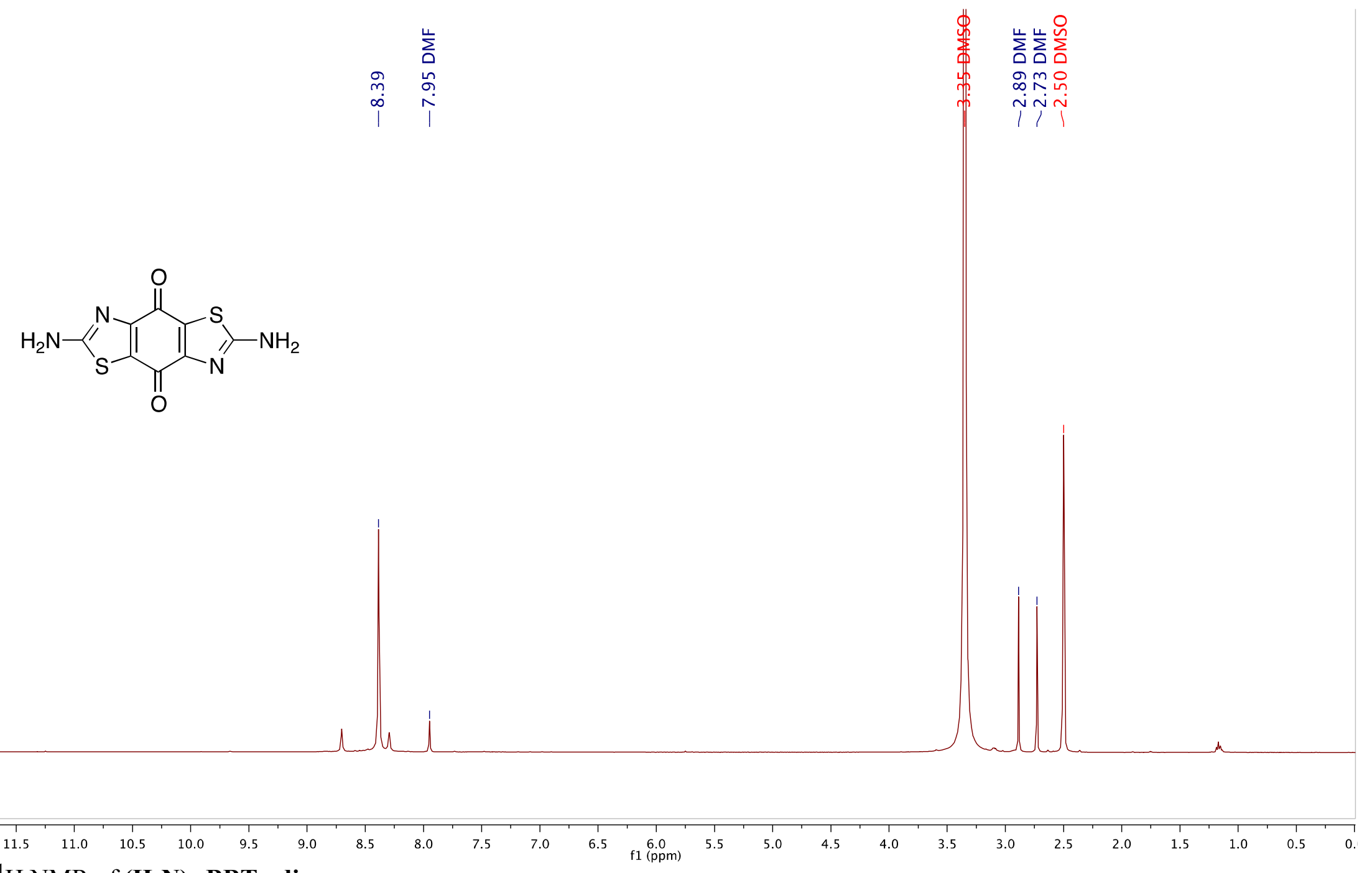

S1. ${ }^{1} \mathrm{H}$ NMR of $\left(\mathbf{H}_{2} \mathbf{N}\right)_{2}$-BBTz-dione. 

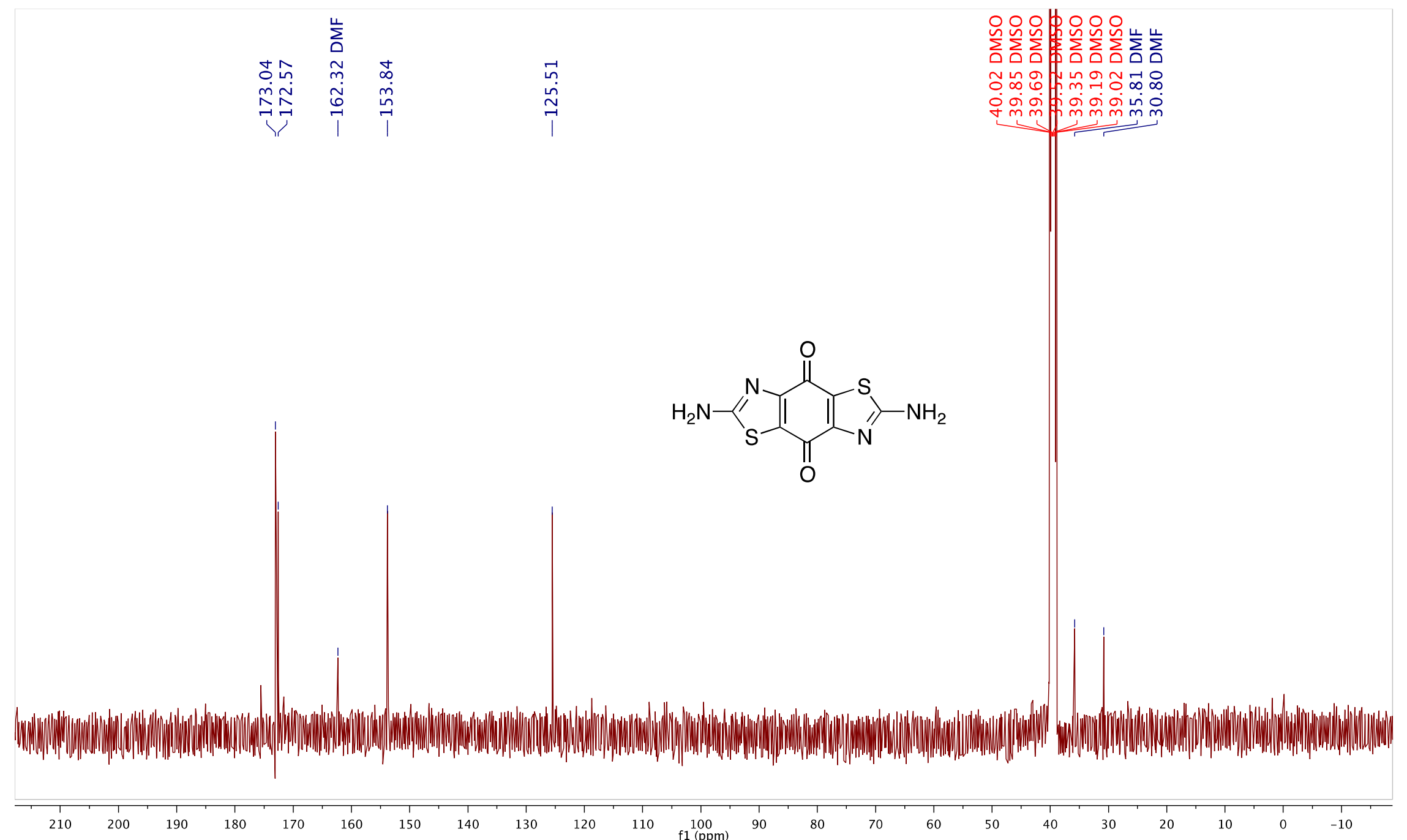

S2. ${ }^{13} \mathrm{C}$ NMR of $\left(\mathbf{H}_{2} \mathbf{N}\right)_{2}$-BBTz-dione. 


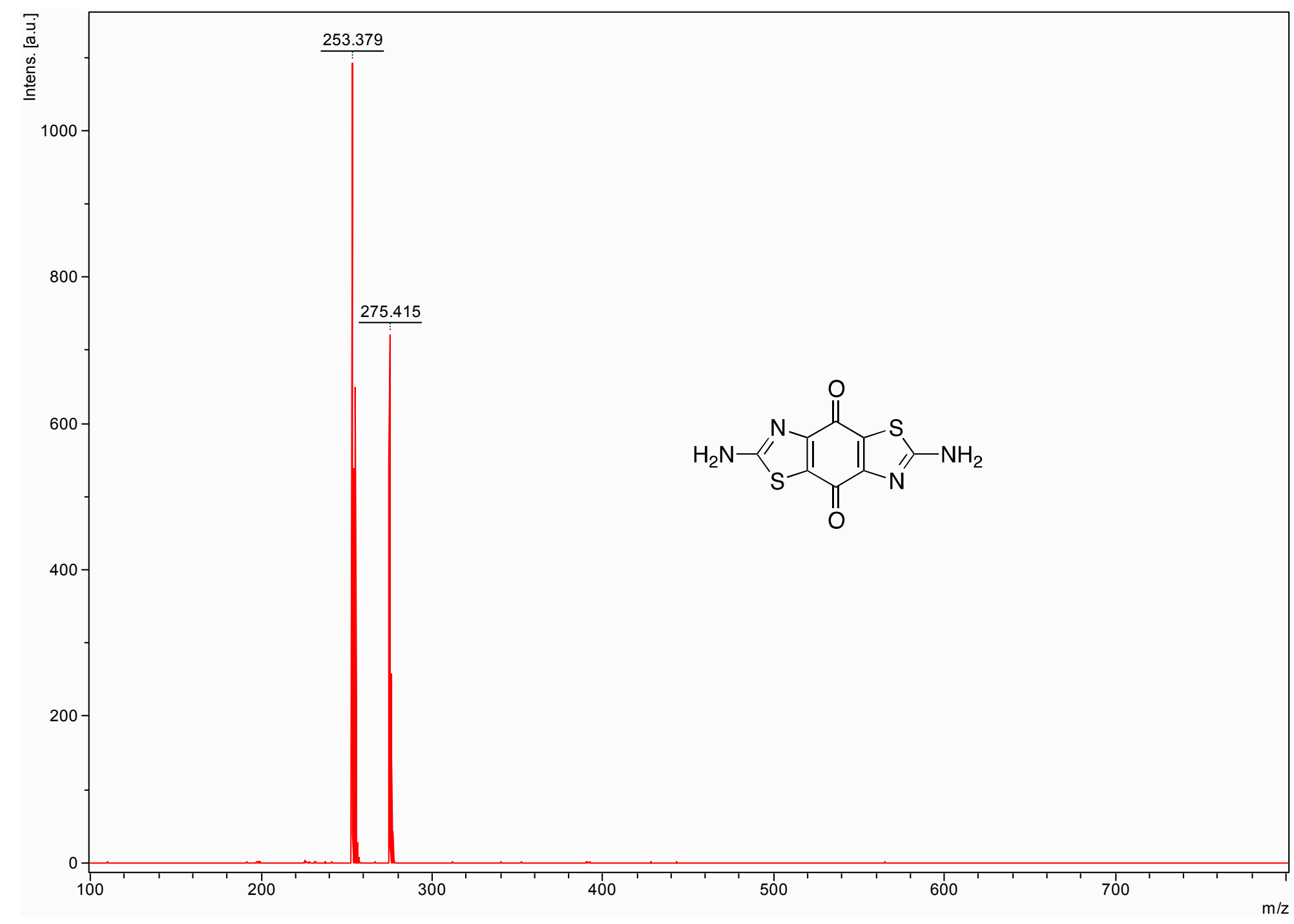

S3. MALDI-TOF of $\left(\mathbf{H}_{2} \mathbf{N}\right)_{2}-$ BBTz-dione. 


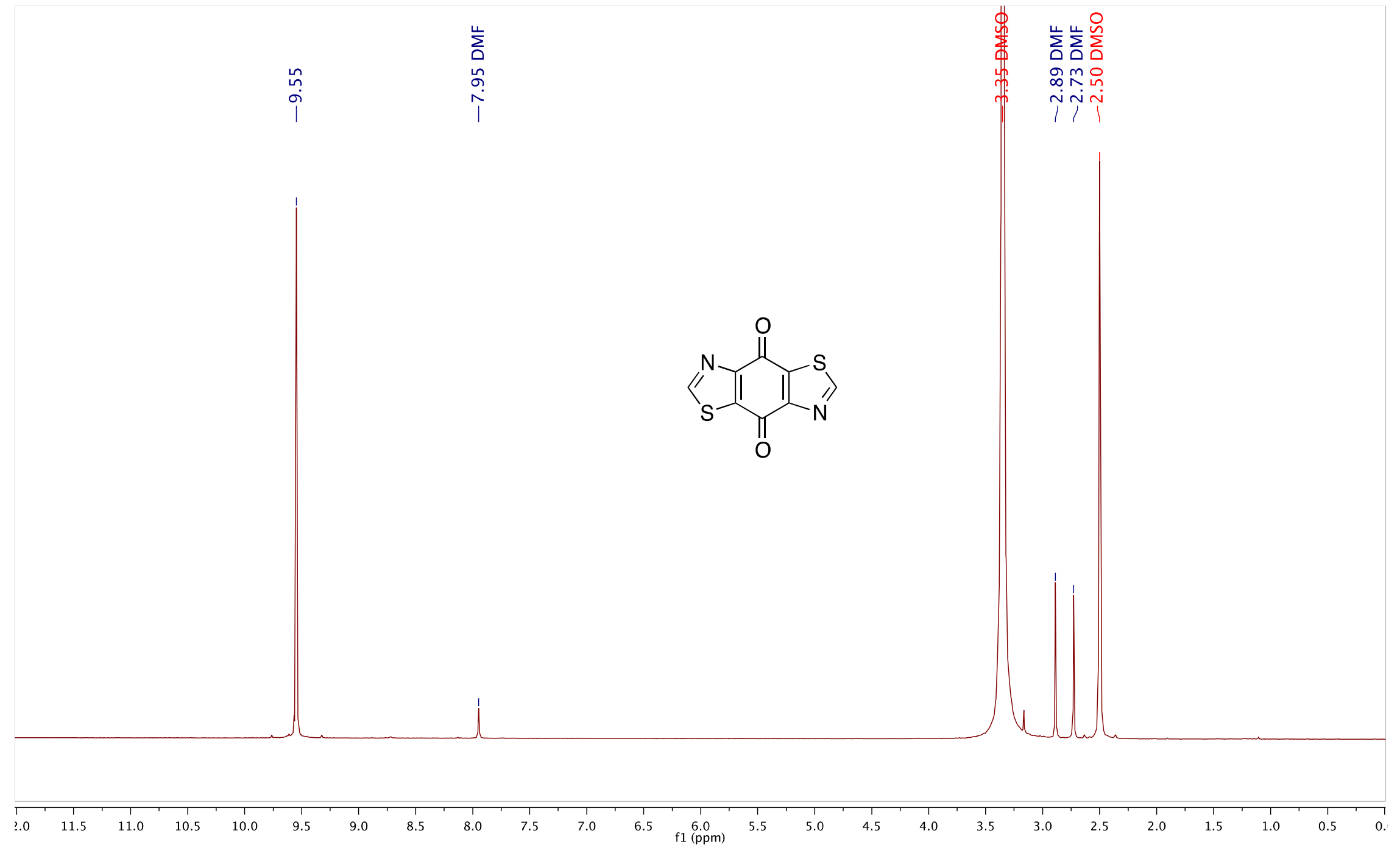

S4. ${ }^{1}$ H NMR of BBTz-dione. 


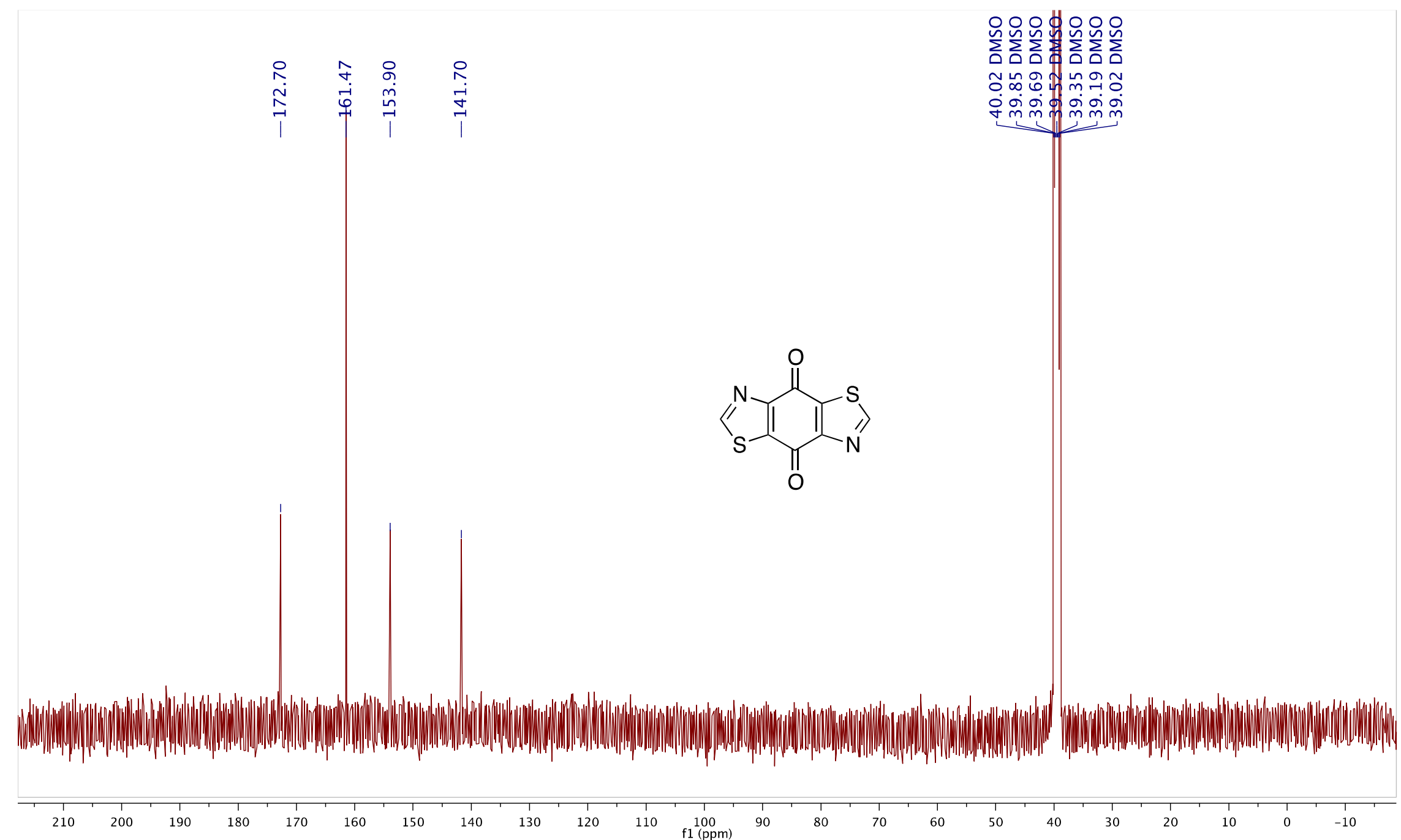

S5. ${ }^{13} \mathrm{C}$ NMR of BBTz-dione. 


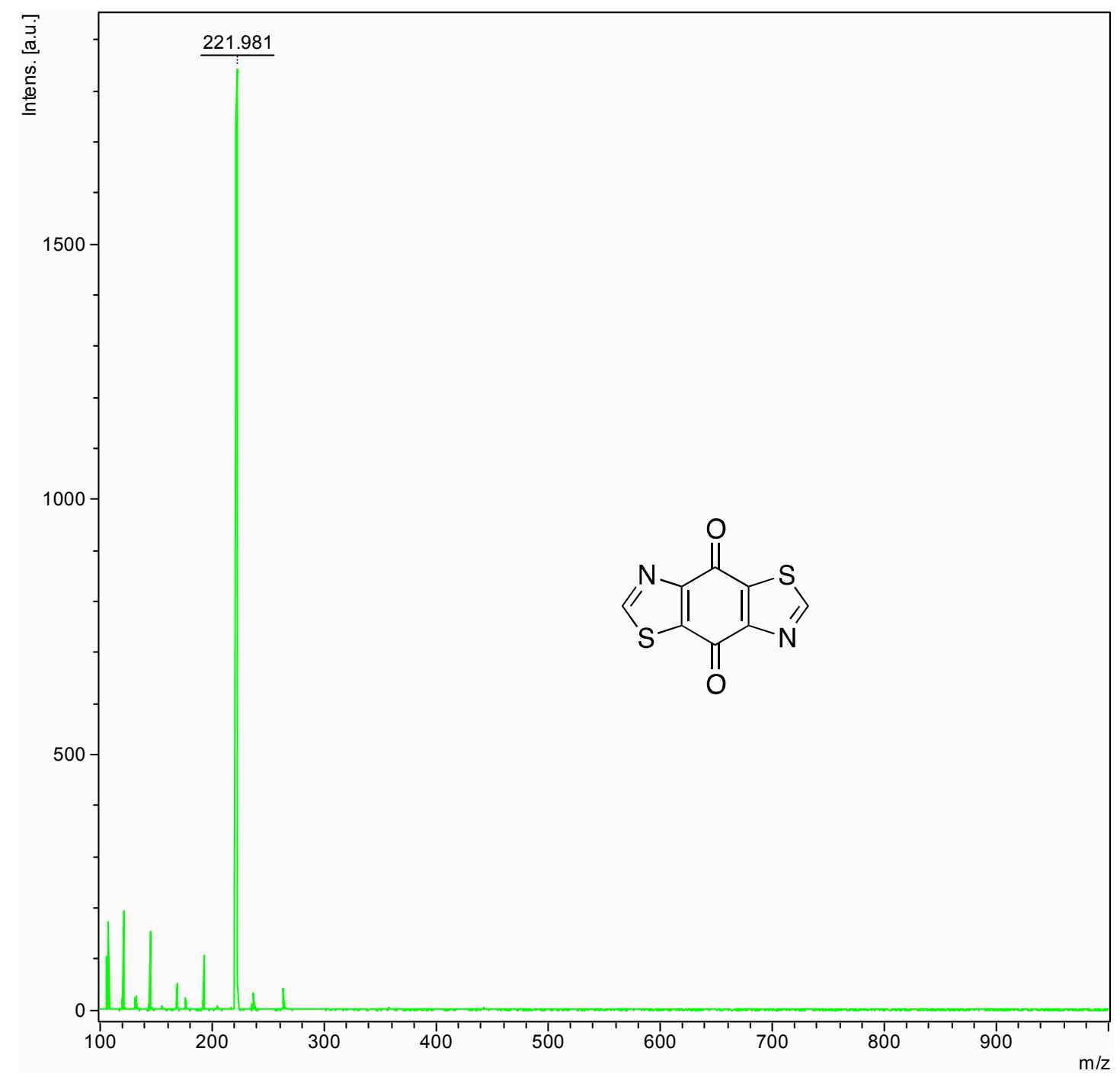

S6. MALDI-TOF of BBTz-dione. 


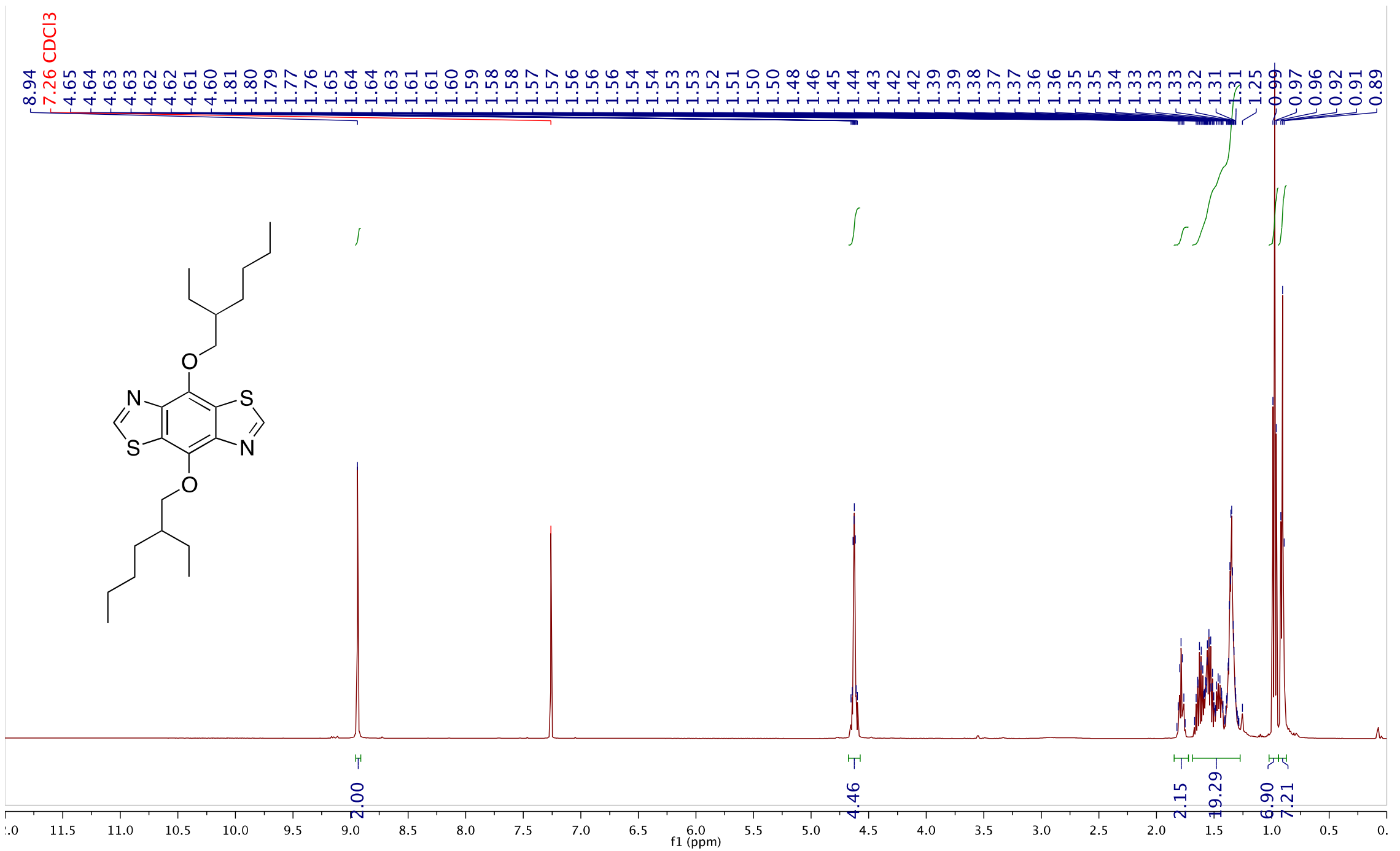

S7. ${ }^{1} \mathrm{H}$ NMR of $\mathbf{B B T z}(\mathbf{O E H})_{2}$. 

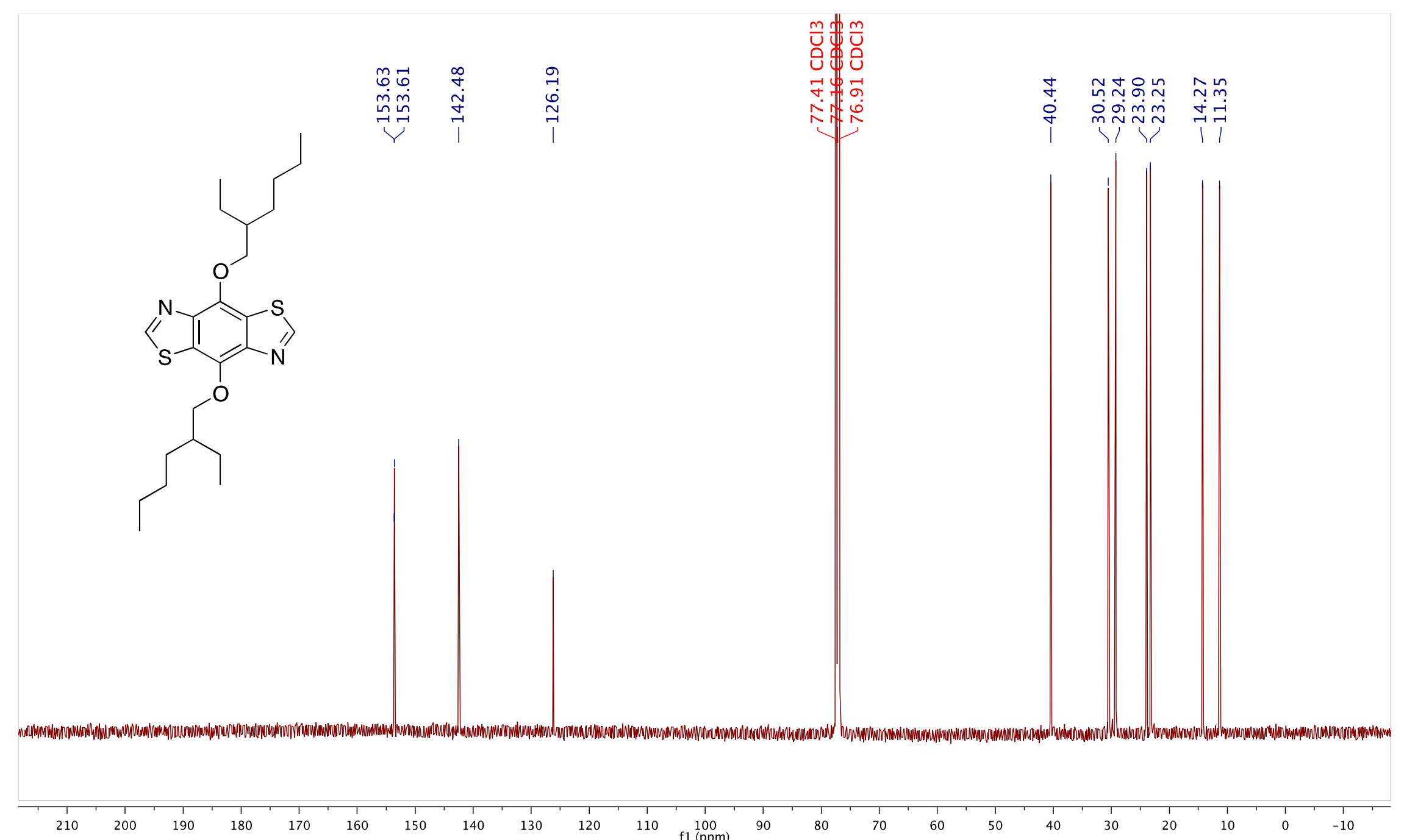

$110 \quad \begin{aligned} & 100 \\ & \quad 1(\mathrm{ppm})\end{aligned}$

90

$80 \quad 70$

60

50

40

30

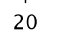

10

S8. ${ }^{13} \mathrm{C}$ NMR of $\mathbf{B B T z}(\mathbf{O E H})_{2}$. 


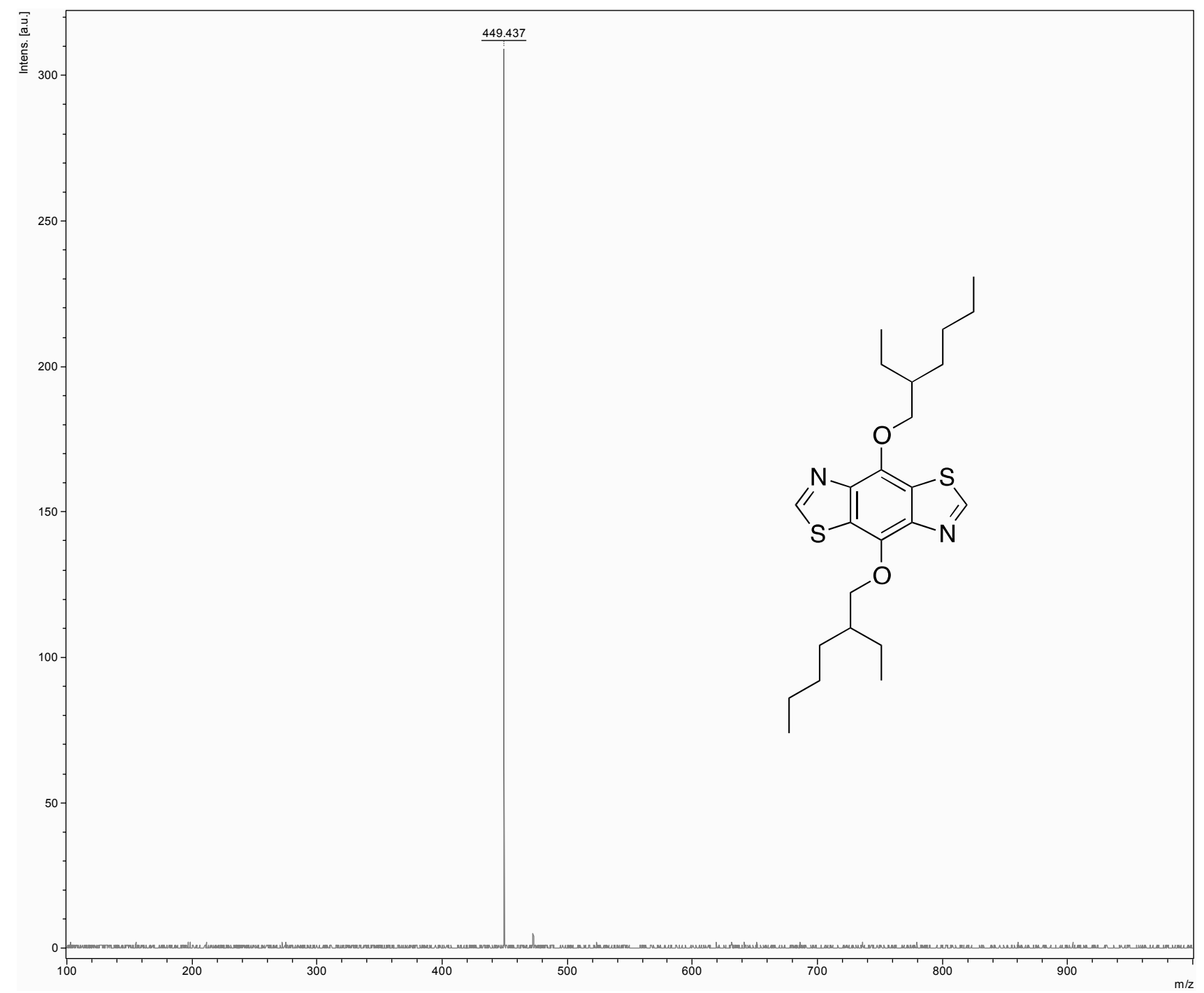

S9. MALDI-TOF of BBTz(OEH $)_{2}$. 


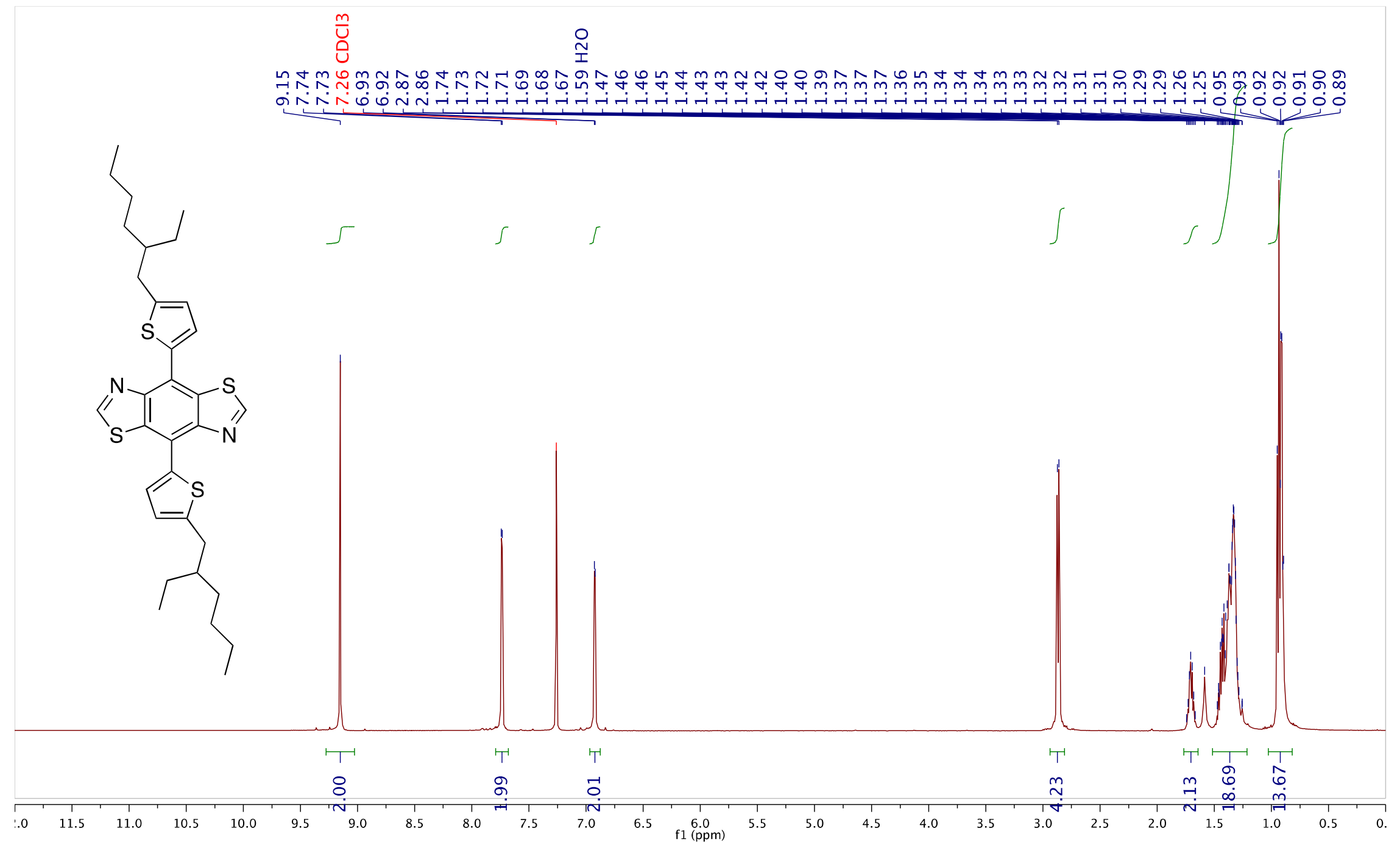

S10. ${ }^{1} \mathrm{H}$ NMR of BBTz(ThEH $)_{2}$. 


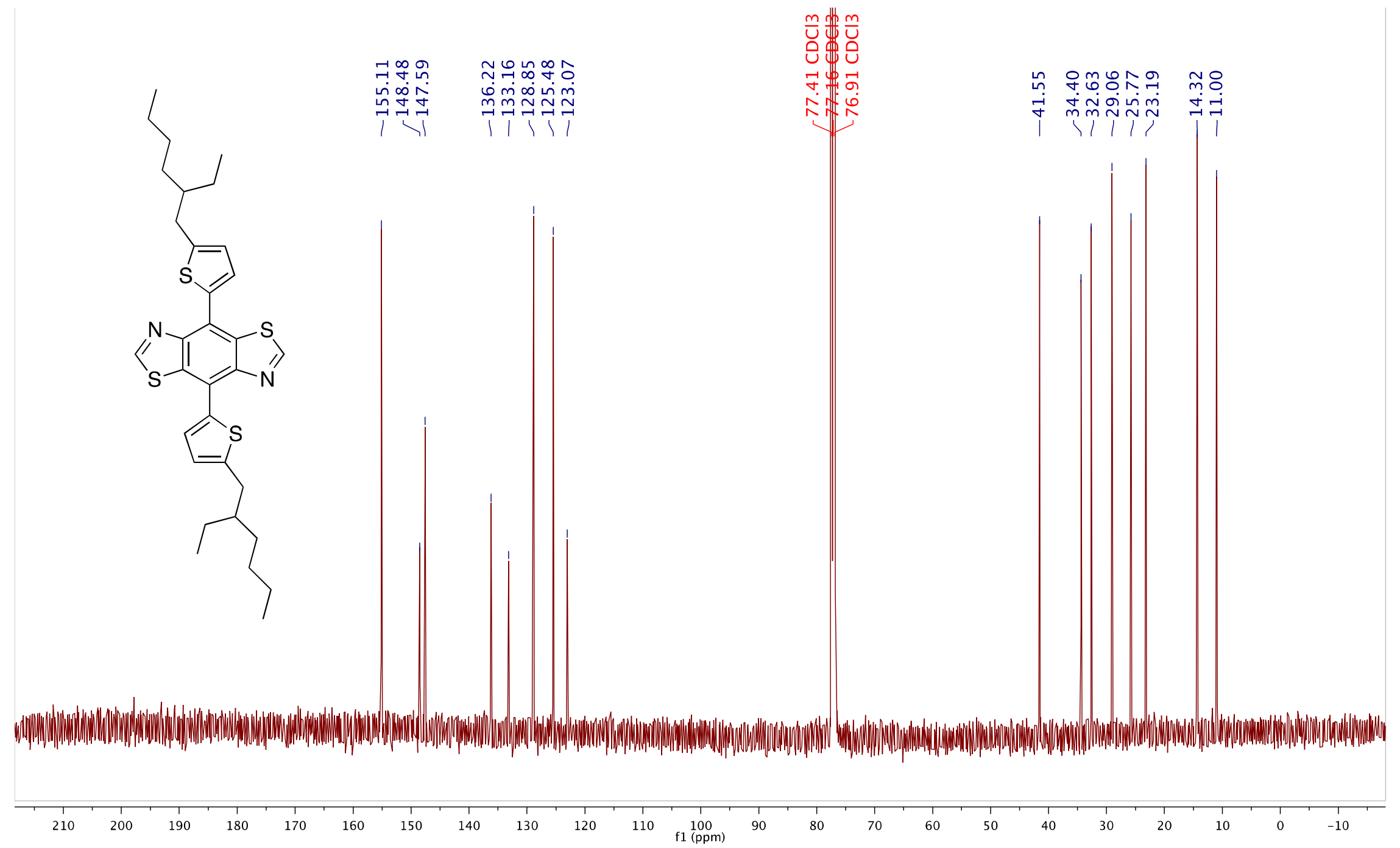

S11. ${ }^{13} \mathrm{C}$ NMR of BBTz(ThEH $)_{2}$. 


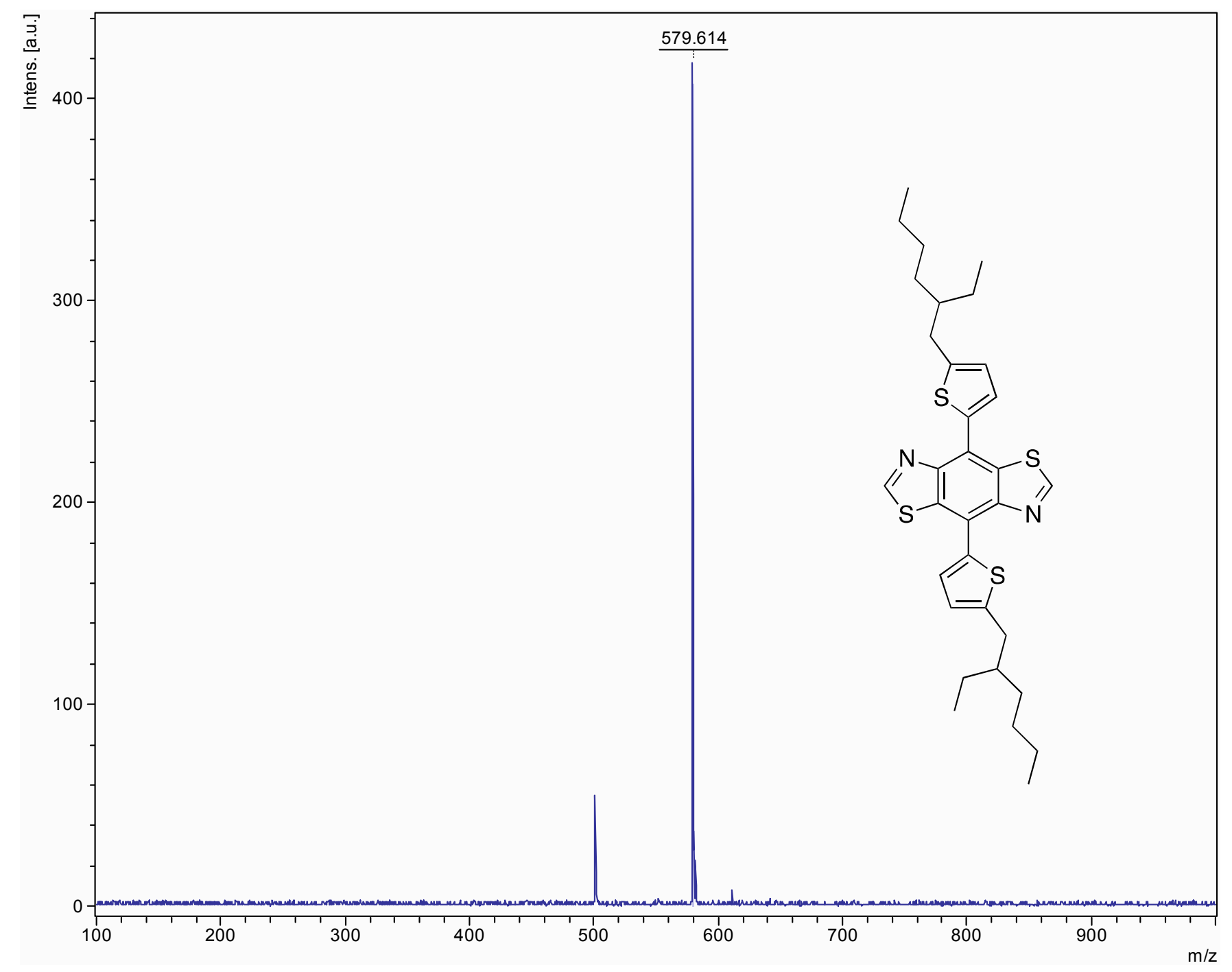

S12. MALDI-TOF of BBTz(ThEH)2. 


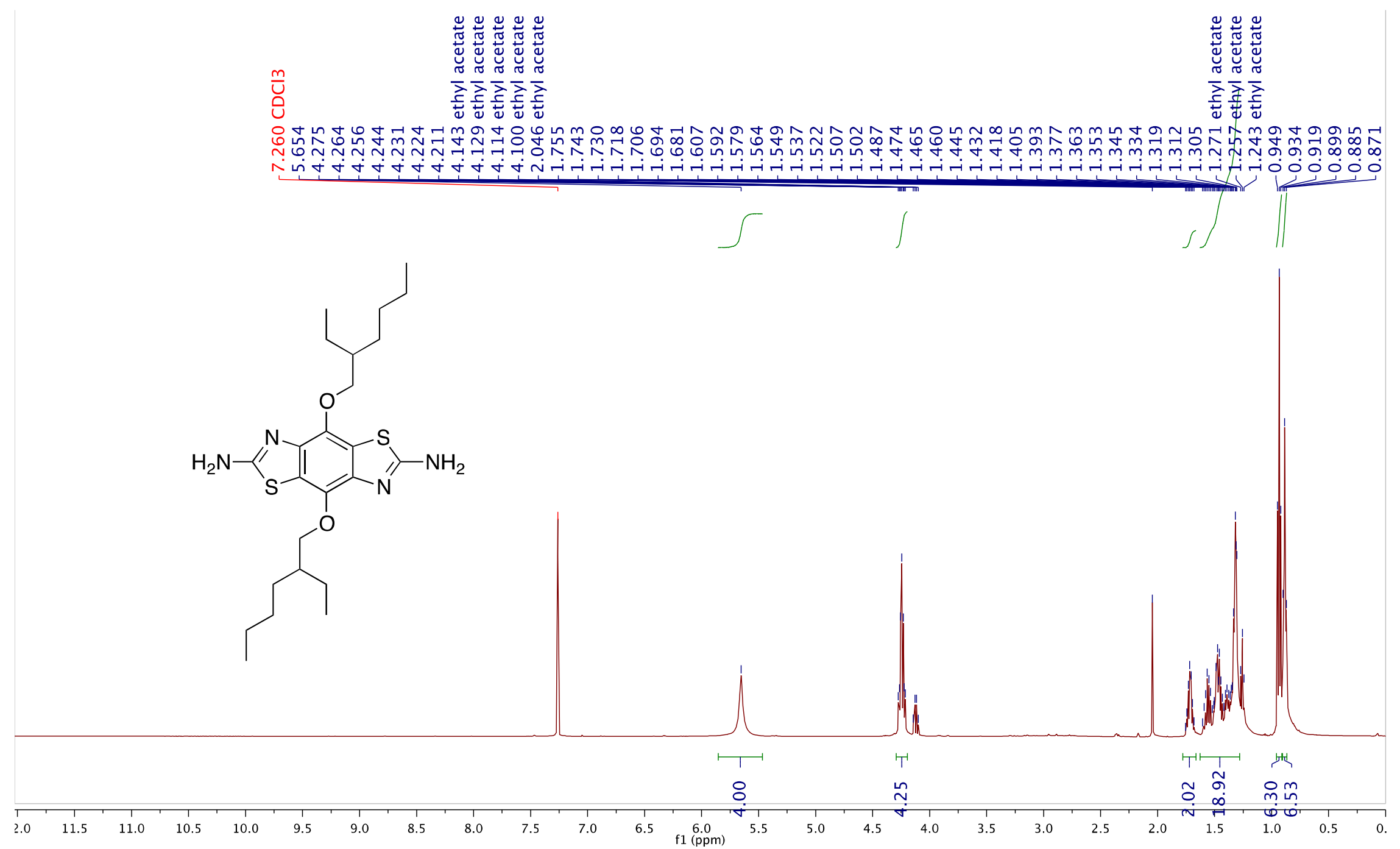

S13. ${ }^{1} \mathrm{H}$ NMR of $\left(\mathbf{H}_{2} \mathbf{N}\right)_{2}-\mathbf{B B T z}(\mathbf{O E H})_{2}$. 

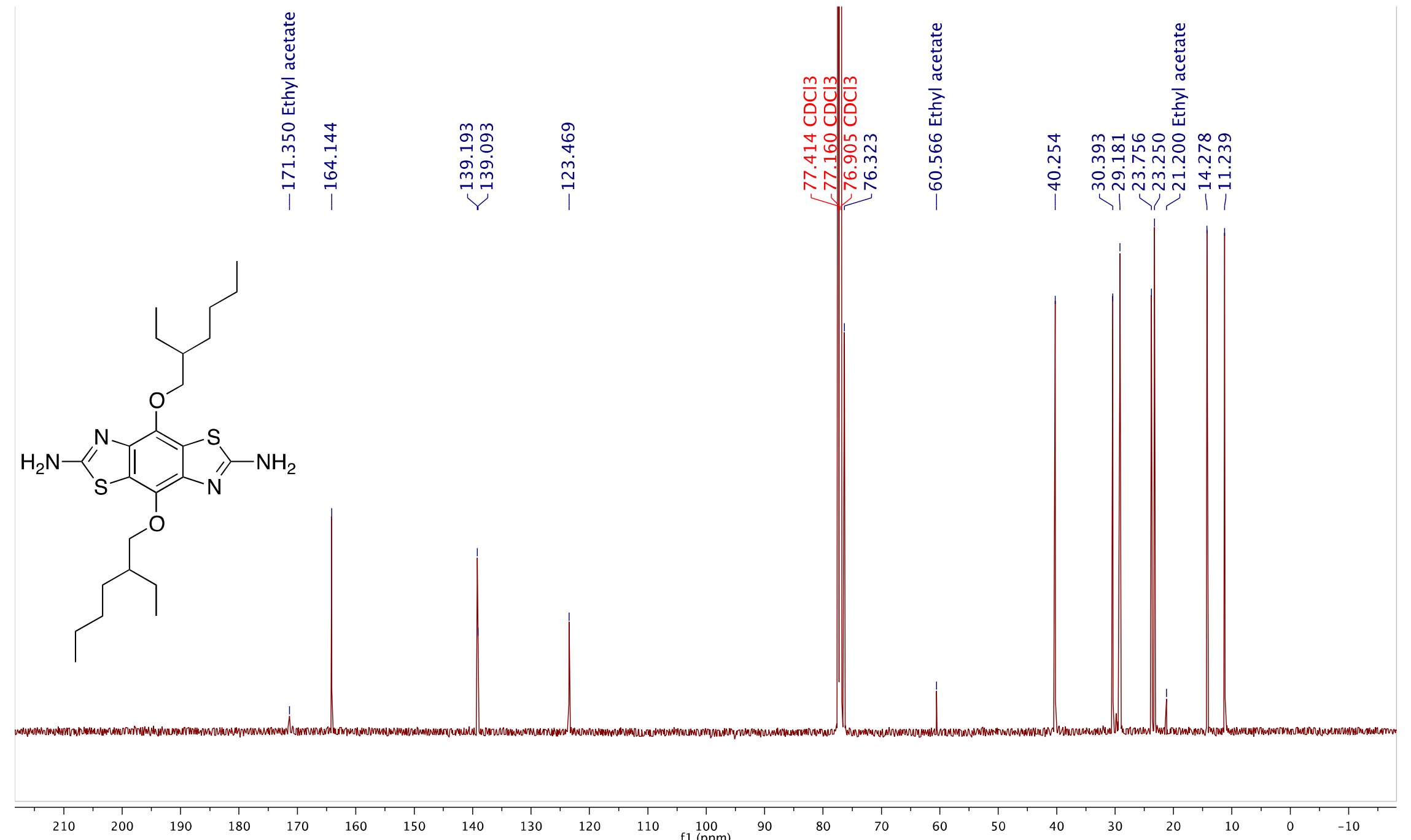

S14. ${ }^{13} \mathrm{C}$ NMR of $\left(\mathbf{H}_{2} \mathbf{N}\right)_{2}-\mathbf{B B T z}(\mathbf{O E H})_{2}$. 


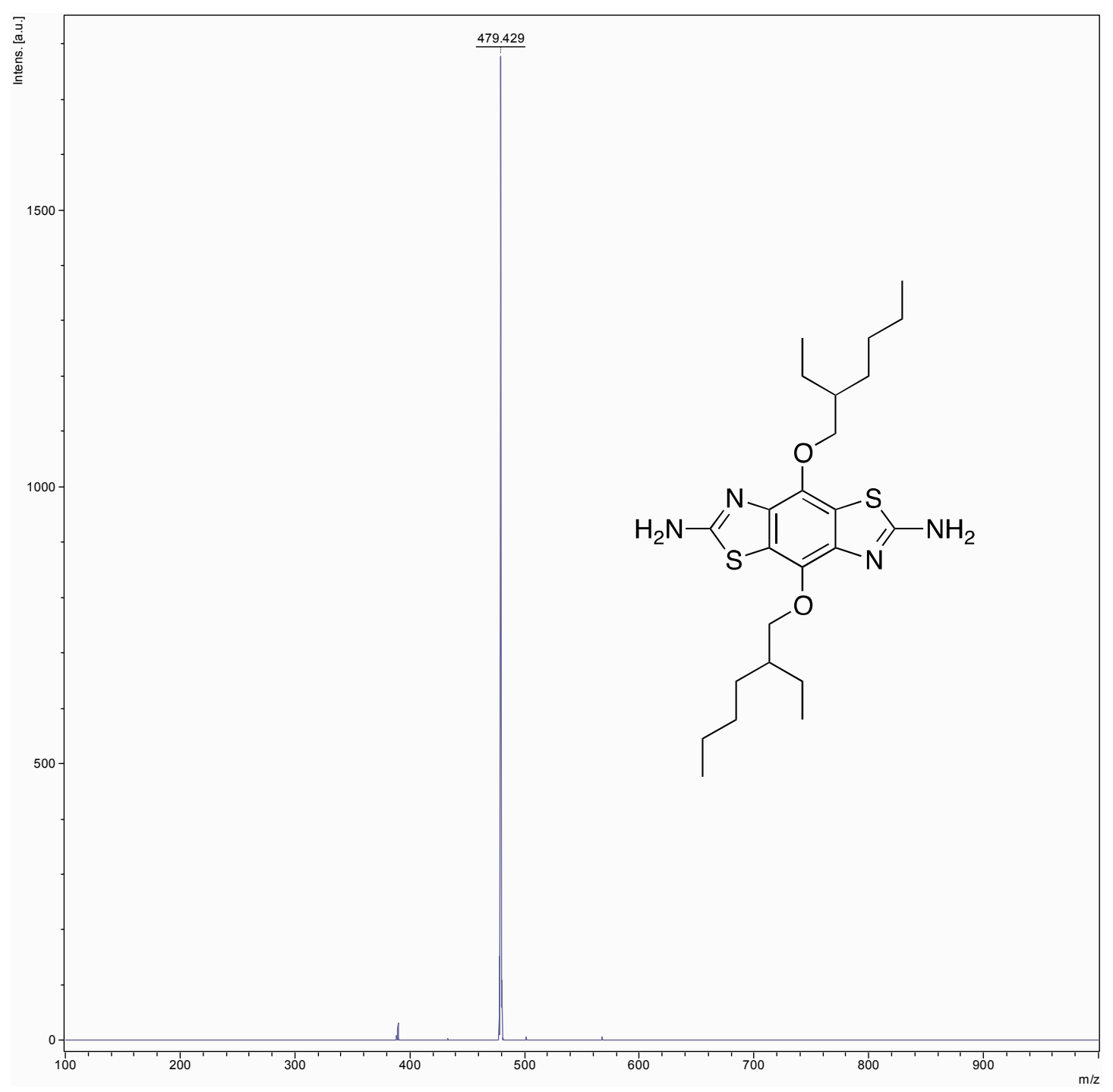

S15. MALDI-TOF of $\left(\mathbf{H}_{2} \mathbf{N}\right)_{2}-\mathbf{B B T z}(\mathbf{O E H})_{2}$. 


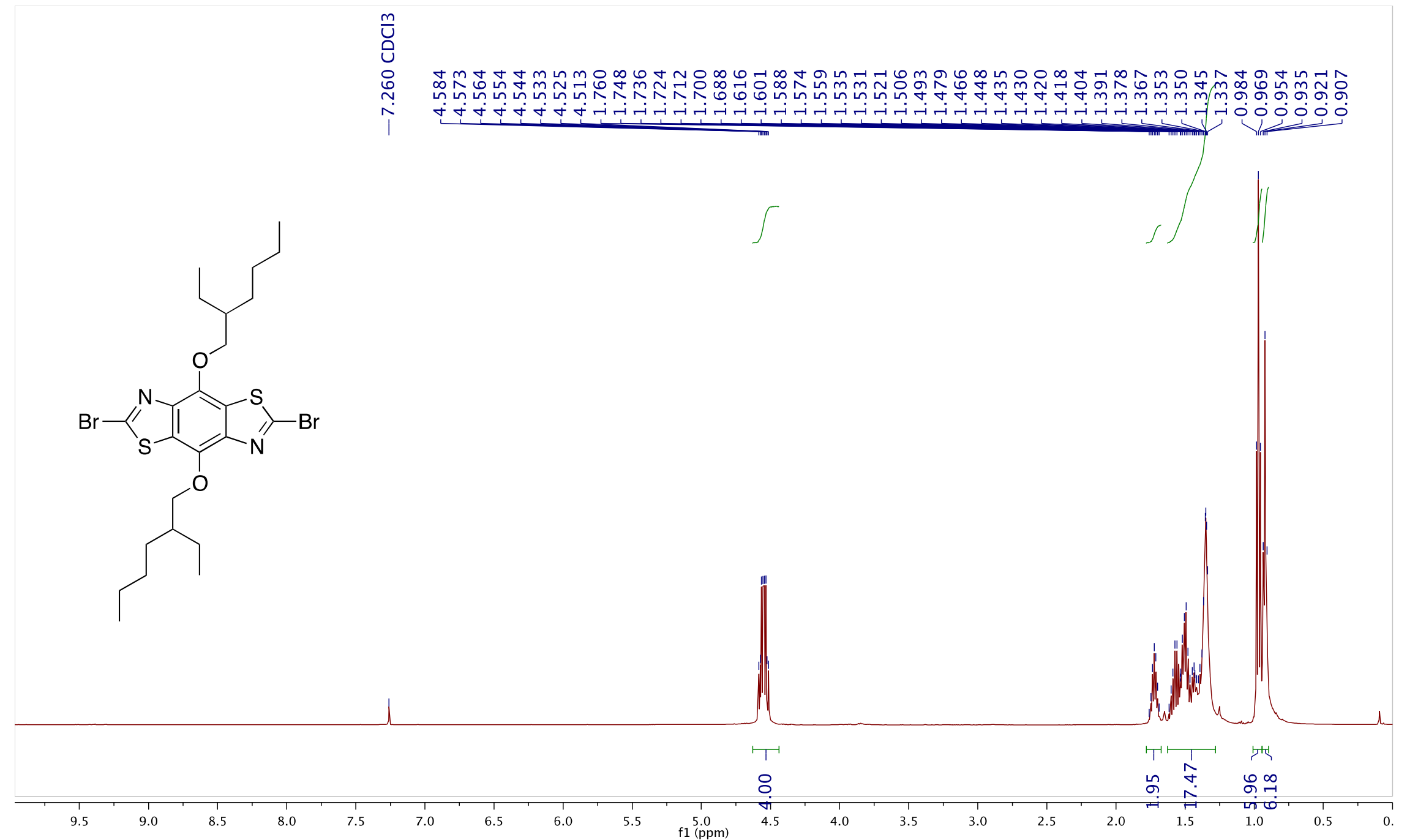

S16. ${ }^{1} \mathrm{H}$ NMR of $\mathbf{B r}_{2}-\mathbf{B B T z}(\mathbf{O E H})_{2}$. 

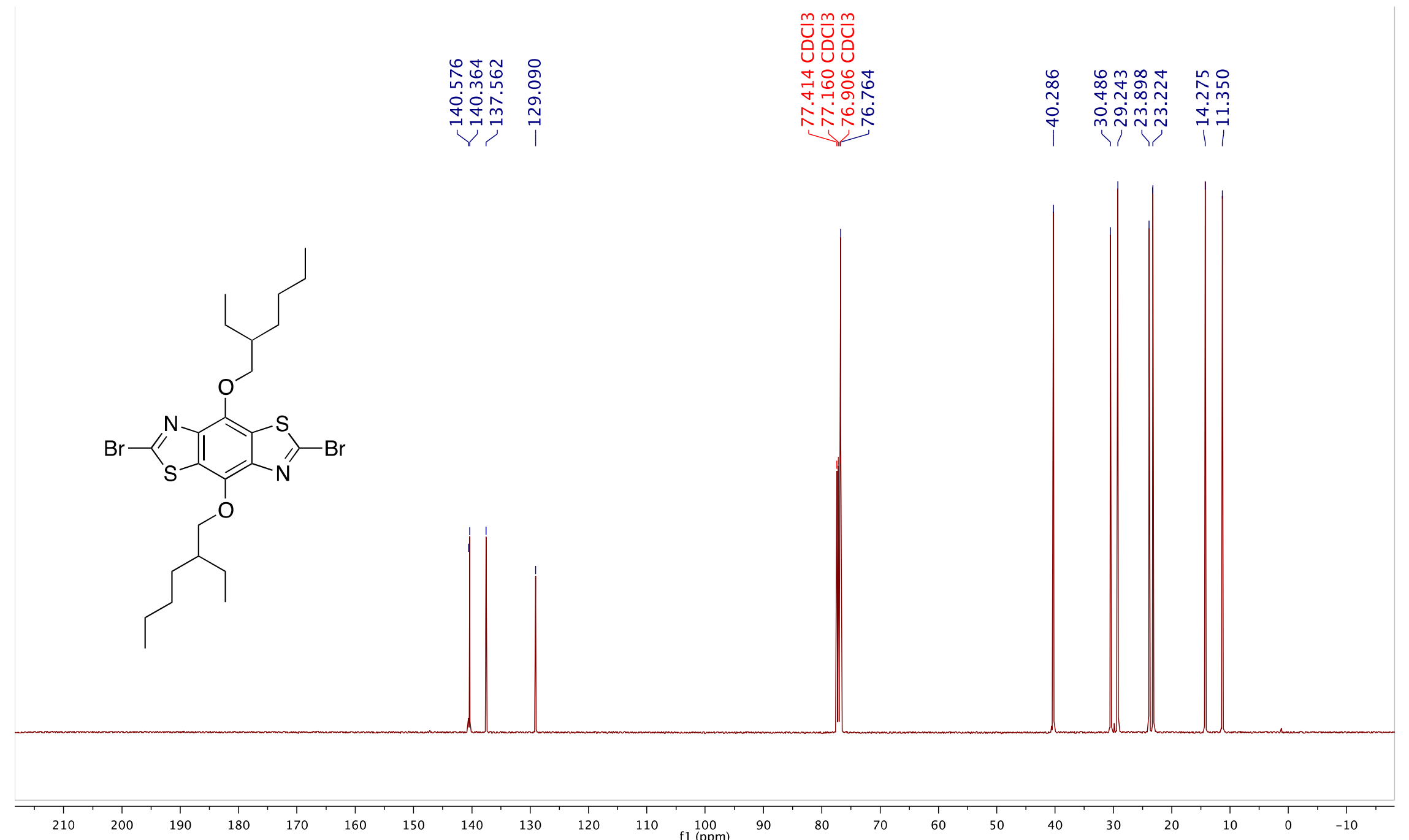

S17. ${ }^{13} \mathrm{C}$ NMR of $\mathbf{B r}_{2}-\mathbf{B B T z}(\mathbf{O E H})_{2}$. 


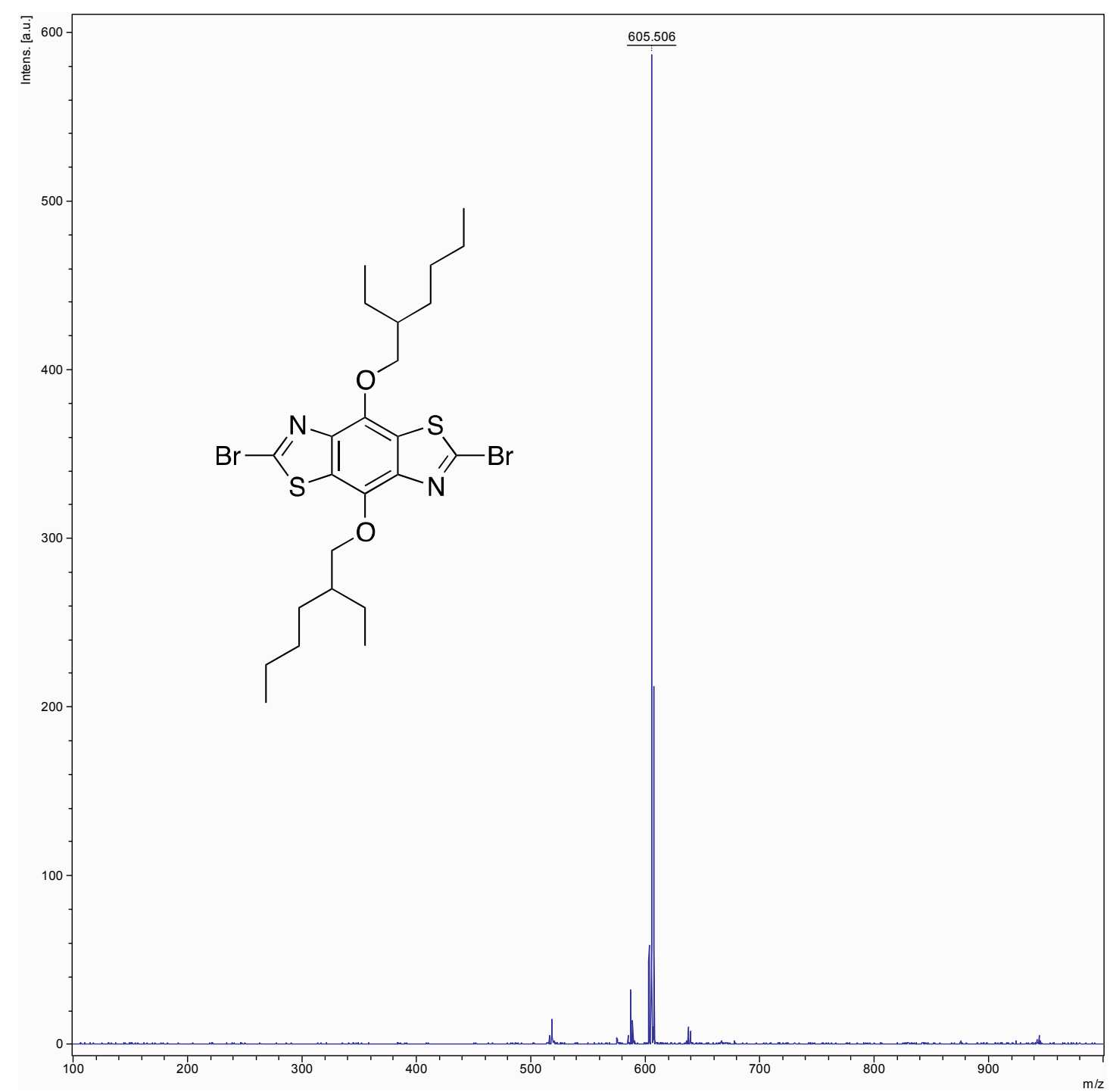

S18. MALDI-TOF of $\mathbf{B r}_{2}-\mathbf{B B T z}(\mathbf{O E H})_{2}$. 

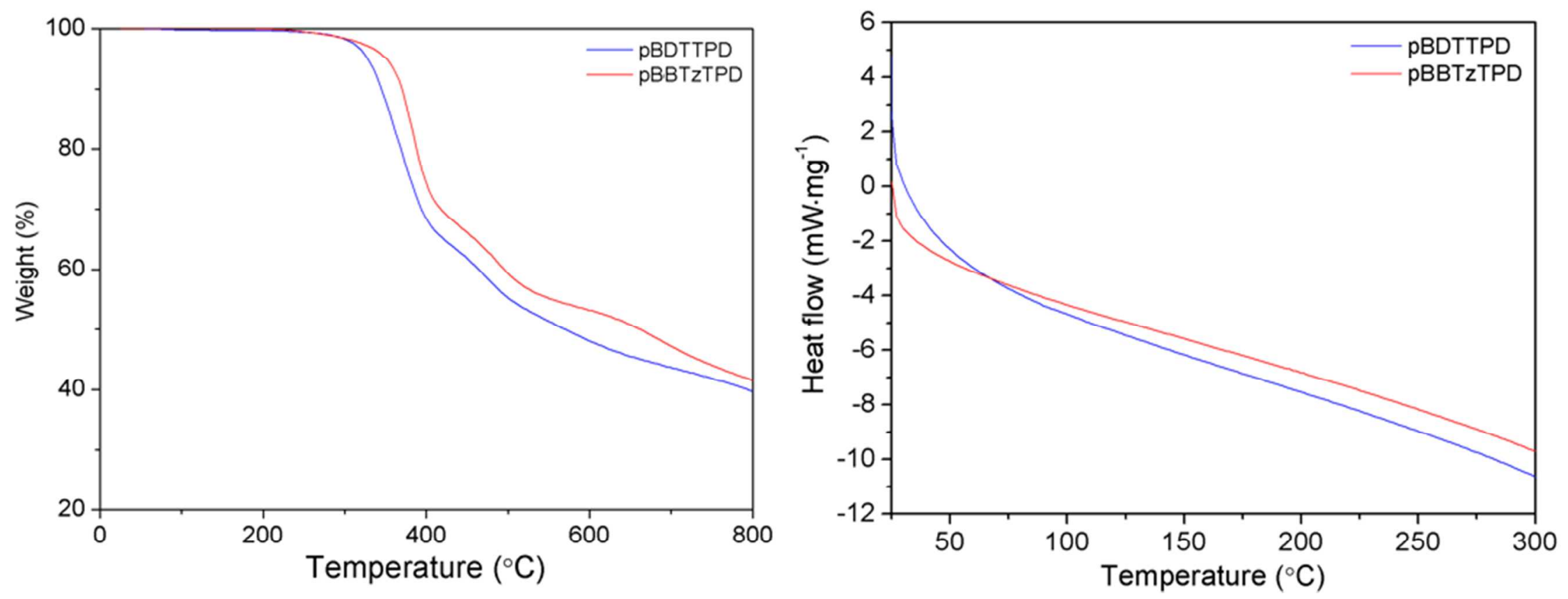

S19. TGA and DSC of the polymers. 

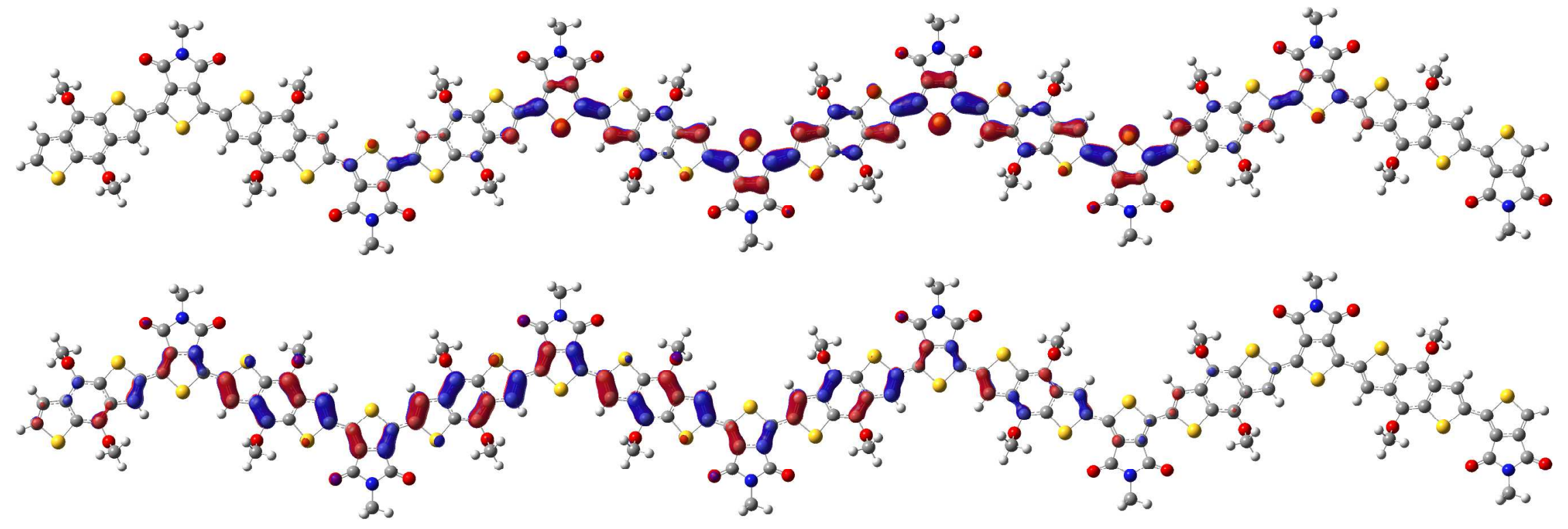

S20. HOMO (bottom, $-5.23 \mathrm{eV}$ ) and LUMO (top, $-2.96 \mathrm{eV}$ ) of pBDTTPD $n=8$. 

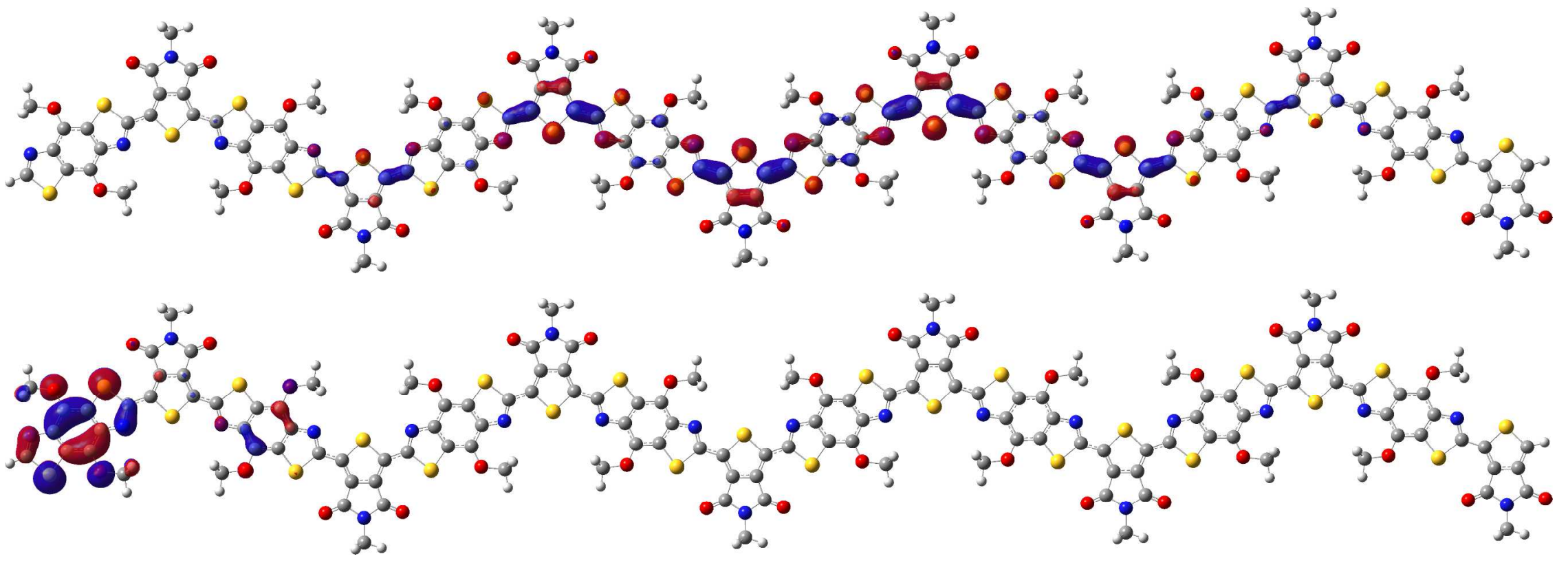

S21. HOMO (bottom, $-5.30 \mathrm{eV}$ ) and LUMO (top, $-3.13 \mathrm{eV}$ ) of pBBTzTPD $n=8$. 